\title{
7 Towards voluntariness in Swedish rape law
}

\section{Hyper-medialised group rape cases and the shift in the legal discourse}

\author{
Gabriella Nilsson
}

\section{Introduction and aim}

In December 2017, the then Swedish Prime Minister Stefan Löfven demanded, 'Sex should be voluntary. If it is not voluntary, then it is illegal' (Aftonbladet, 17/12 2017). ${ }^{1}$ The background of his statement was the recommendation made already in 2016 by the Sexual Offences Committee to introduce a consent-based regulation in the sexual offences legislation instead of the force-based existing legislation (SOU, 2016:60). Already prior to the inquiry by the Sexual Offences Committee, the legislation had been subjected to two recent reviews, resulting in an extensive reform in 2005 and legislative amendments in 2013. On both occasions, consideration was given to amending the legislation to base criminal liability on the absence of consent, but it was decided against such a proposition. In 2016, however, the conclusion was the reverse:

Even though several amendments have been made to sexual offences legislation in the past decade, there are still situations where sexual integrity and self-determination are violated and where it is doubtful whether there is sufficiently strong protection from the violation under criminal law. [...] In the choice between supplementing the present legislation and changing it completely, we have concluded that the law has to be changed.

(SOU, 2016:60)

Thus, the committee proposed that 'criminal responsibility is borne by a person who performs sexual intercourse or another sexual act that, with regard to the seriousness of the violation, is comparable to sexual intercourse, with a person who is not participating voluntarily' (SOU, 2016:60, p. 43). Additionally the punishable area was expanded by the introduction of a liability for negligence, including both cases where the perpetrator actually realised that it might be the case that participation in a sexual act was not voluntary, but still chose to perform the sexual act, and the cases where the perpetrator could and really ought to have done something to come to a realisation of whether the participation was voluntary or not (SOU, 2016:60, p. 53). 
The Swedish government chose to propose the change that was recommended by the committee and, on 23 May 2018, the parliament voted for a legislation based on the requirement of consent (Govt. Bill. 2017/18:177). On 1 July 2018, the new legislation entered in force (SFS 2018:618).

Internationally, this legal shift coincides with an increased criticism the last few decades towards the judicial procedure and the legal construction of rape, and a great number of changes in sexual offences legislation (Bumiller, 2008; McGlynn \& Munroe, 2010; Spohn \& Horney, 2013). Nonetheless, it is surprising how little scope the legislative changes in other countries, in particular the countries where consent-based legislation has come into force far earlier than in Sweden, have been given in the Swedish debate on sexual offences.

The main argument in this chapter is that in Sweden, this legal shift was the result of a discursive process that since the mid-1990s, in particular, was taking place in news reports and debate about the legal handling of a number of hyper-medialised Swedish group rape cases (cf. Wennstam, 2002; Leijonhufvud, 2015; Nilsson, 2018). The aim is to highlight how a gradual change towards voluntariness was reflected in, and largely pushed by, news reports and debate about these cases.

\section{Material}

The chapter uses empirical material gathered as part of a larger study of how rape is portrayed in Swedish news media from 1990 to 2015 (see Andersson et al., 2016). Within the scope of this study, an initial search was conducted of all newspaper articles about rape in the tabloid Expressen. In the first overview of these articles, it was apparent that a number of particularly hyper-medialised cases of group rape seemed to work as starting points and discursive arenas to debate legislation and call for legal changes (Nilsson, 2018). These cases were in particular the so-called 'Södertälje case' (1995); the 'Rissne case' (2000); the 'Tumba case' (2003); the 'Husby case' (2004); the 'Motala case' (2004); the 'Stureplan case' (2007); the 'Tensta case' (2013) and the 'Bottle rape' (2013).

An additional search was conducted where all newspaper articles concerning these cases, both news reports, editorials and opinion pieces, published mainly in the six largest Swedish morning papers and tabloids, were retrieved. The articles were closely read focussing on how they had influenced a legislative change, including how new terms was introduced, discussed and implemented. In this chapter, the four cases that most clearly illustrated the gradual change towards consent-based legislation have been selected for the analysis. In the analysed articles, aside for the journalists themselves, the voices from the courts are heard in the form of lawyers and prosecutors involved in the cases, as well as is the voice of the legislature, usually represented by the minister of justice. 


\section{Analytical framework}

The analytical starting point is a discourse theoretical perspective (Laclau \& Mouffe, 1985). Central to discourse theory is for the meaning of language to be regarded as contingent. By relating different terms to one another in a certain discourse, their meaning is (temporarily) fixed. Accordingly, a discourse can be described as a context in which the ambiguous meanings of the central terms, what Laclau and Mouffe call nodal points, have been reduced for the purpose of certainty and clarity. The legal discourse is one context in which the certainty and clarity of the nodal points is particularly important, especially from the perspective of legal certainty. In the legal discourse on rape, the nodal points are general legal principles but also the specific terms stipulated in the legislation, e.g. force and intent.

A discourse is influenced not only by the terms it includes, but also by the exclusion of terms what Laclau and Mouffe describe as the discursive field. As a discourse such as the legal discourse is constituted in relation to the surrounding discursive field, it risks being undermined by the articulations taking place therein. In this chapter, the news articles on rape are regarded as an arena where the discursive field took shape, e.g. by gradually introducing a debate about the alternative terms 'consent' and 'negligence'. The chapter will analyse the process of the legal discourse being gradually influenced by articulations on the discursive field.

\section{The Södertälje case, 1995}

At the time of the Södertälje case, the Swedish rape legislation was a gender-neutral version of the Penal Code (PC) from 1965, implemented in 1984. The offence of rape was regulated as follows:

A person who by violence or threat which involves or appears to the threatened person to involve an imminent danger, forces another person to have sexual intercourse or to engage in a comparable sexual act is guilty of rape [...]. Causing incapacitation or a similar state shall be regarded as equivalent to violence.

(SFS, 1984:399, PC, Chapter 6, Section 1)

In this section of law, the terms 'forces', 'violence', 'threat' and 'causing incapacitation' appeared as nodal points for how the offence of rape was to be defined.

The offence of sexual exploitation is also relevant and was laid down in law as follows:

A person who induces another person to engage in a sexual act by gross abuse of his or her dependent state or by improperly taking advantage of the fact that the he or she is helpless or in some other state of incapacitation $[\ldots]$ is guilty of sexual exploitation.

(SFS, 1984:399, PC, Chapter 6, Section 3) 
The term 'taking advantage' and the wording 'helpless or in some other state of incapacitation' here appear as nodal points in the legal discourse. At this point, it is relevant to note the distinction between causing incapacitation (prerequisite for the offence of rape) and exploiting someone who is helpless or already in some other state of incapacitation (prerequisite for the offence of sexual exploitation). It was in this specific legal context that the Södertälje rape was committed.

In July 1995, an 18-year-old woman, called Anna by the media, was at a restaurant in Södertälje. She was very intoxicated. A 22-year-old man offered her a lift home to the smaller town outside Södertälje where she lived. Once inside the car, she discovered three other young men. Three of the men had repeated sexual intercourse with the woman in the car. Thereafter they took her to an apartment where further vaginal and oral sexual intercourse was carried out. They then promised to take the woman home but, on the way, they stopped the car and one of the men again demanded that she have intercourse with him. The woman, who at this point had sobered up, then bit him in the throat. After this the woman was left and was able to call her step-father to be picked up. ${ }^{2}$

Almost two years later, Södertälje District Court, the lowest court in Sweden, sentenced three of the men to imprisonment for sexual exploitation because they, according to the newspaper Expressen, 'had exploited the girl who, due to her severe intoxication, had been helpless' (24/4 1997). Another newspaper, Aftonbladet, highlighted the term helpless and further developed the description of what this condition means: "[The court] was of the opinion that Anna was completely helpless. She was very intoxicated, she was petrified, she was alone' (24/4 1997). The term helpless was here defined in the everyday sense of the word in terms of feelings 'Anna' experienced. Being helpless meant feeling petrified and alone.

Despite the prosecutor choosing to classify the offence as sexual exploitation rather than rape, the judgement does not seem to have made visible any discrepancy between the legal interpretation of the assault and the general conception of justice. However, the word the newspapers borrowed from the judgement to describe Anna's fear was not the colloquial 'helpless' but the legal term 'helpless state' - one of the nodal points in the legal discourse. In this discourse, the colloquial term's potentially ambiguous meaning was presumed to be fixed in an unambiguous manner - not dependent on 'Anna's' subjective experiences. It would later become evident that the disagreement about the definition of the term helpless state revealed the inherent contingency of the legal discourse and thereby created scope for a struggle for precedence of interpretation.

An appeal against the judgement in the Södertälje case was made to the higher court, the Svea Court of Appeal, which acquitted the three men. The newspaper Dagens Nyheter (DN) reported the Senior Judge of Appeal's explanation in which a distinction was made between the legal nodal point helpless state and the colloquial word helpless: 'The girl was not in a helpless state. Nor 
was she in a state of incapacitation. She could both walk and talk. The section that concerns sexual exploitation is there to protect people who are unconscious or passed out' (DN, 30/4 1997a). This then was another definition of the word helpless - to be unconscious or passed out. In the legal discourse, being able to 'walk and talk' was the same as not being in a helpless state. The court of appeal's narrowing of the definition, which resulted in an acquittal, can be seen as an attempt to fixate the legal discourse by excluding the alternative interpretations.

In the discrepancy between the court of appeal's definition and that of the media, a dilemma arose. Could it really be possible to do what the three men had done and walk free? (DN, 30/4 1997a)

Neither the court nor now [the senior judge of appeal] discuss the possibility that an even moderately intoxicated girl weighing $45 \mathrm{~kg}$ may have felt completely helpless against three men, particularly considering that she said she had been very afraid of them. What ability could she have had to fight off the three with any success?

(DN, 6/5 1997)

The newspaper here sought an interpretation of the term helpless state as both a subjective experience (that she had 'felt helpless') and a physical fact (her weight in relation to the number of men). The wording can be seen as a critique of the fact that the legal definition of the term helpless state is not consistent with the general conception of justice. It was asserted in an opinion piece that 'the perpetrators had been acquitted, not because the court was convinced of their innocence, but because the lawyers, through their sacred law, have turned the reality of what happened into something only they can understand!' (DN, 30/4 1997b). The hegemony of the legal discourse was questioned here by talking sarcastically about the 'sacred law'.

The Senior Judge of Appeal responded to this criticism by stressing that the men may have committed an offence other than sexual exploitation, implying rape, but that this had not been examined in the court of appeal as the prosecution only pertained to sexual exploitation (Svenska Dagbladet, SvD, 3/5 1997). This statement caused some debaters to instead direct their criticism at the public prosecutor's decision not to prosecute the men for rape:

It is obvious that the prosecutor made a misjudgement when he declared himself satisfied with the alternative classification of the offence as sexual exploitation in eight of the nine assaults. In the appeal, the prosecutor should have maintained that rape had taken place in these cases as well.

(SvD, 4/5 1997)

The prosecutor regretted this but revealed his justification: 'I knew that I would have problems proving that there had been violence or the threat of violence. That is why I assessed there to be more chance of them being convicted of sexual exploitation' (DN, 30/4, 1997a). The prosecutor here portrayed the 
choice of how to classify the offence as tactical in order to achieve any kind of conviction. In another article, the prosecutor said it was a problem that the offences rape and sexual exploitation function as each other's opposites so that cases like this 'fall between the cracks' (Expressen, 24/4 1997). With this statement, the prosecutor revealed that he did not necessarily comply with the legal understanding of what constitutes rape, which gave the media legitimacy in their critique of the judgement.

It is the task of the highest court in Sweden, the Supreme Court, to clear up this type of uncertainty around how the law is to be interpreted - to fixate the legal discourse - by establishing certainty and clarity through its judgements. The Supreme Court can be seen as the actor that, in addition to the legislature, formulates the content of the legal discourse by literally having precedence of interpretation. In the Södertälje case, the Supreme Court decided to concur with the district court and convict the men of sexual exploitation by, in the words of the news service Tidningarnas Telegrambyra (TT), 'broadening the term "helpless state"" (TT 10/9, 1997). The Prosecutor-General, who lead the prosecution, opened up the possibility of including a more empathetic assessment of what it means to be helpless in the legal discourse:

The court of appeal made it too easy for itself when it dismissed the potential to interpret what the law means by helpless state. Anna was intoxicated and surrounded by seven men, entirely unknown to her, in unknown locations. She was extremely vulnerable and thus in a helpless state.

(DN, 25/8 1997)

Here further examples were given of what it could mean to be helpless being 'vulnerable' to 'unknown men' in 'unknown' locations. Through the Supreme Court's precedence of interpretation, the meaning of the term helpless was fixated and it was determined that a 'broadened term' would apply.

However, the Södertälje case also initiated a discussion about the need to amend the sexual offences legislation. Even prior to the Supreme Court judgement, the then minister of justice, Laila Freivalds, criticised the justice system and threatened to amend the legislation if the judgement was not the one she favoured: 'If the Supreme Court decision was to indicate the criminal law has shortcomings in terms of the protection it provides against sexual assault, I will not hesitate to immediately ensure that those shortcomings are rectified' (SvD 30/5 1997). Another actor, the legislature, thus stepped into the discursive field. From the legislature's perspective, it is, in order to encourage compliance with the law, key that the wording of legislation and its application are closely aligned with the general public's conception of justice. Ahead of the Supreme Court hearings, there were seemingly two possible outcomes, a judgement that set precedent consistent with the general conception of justice or a change of the wording of the law. 
The Prosecutor-General indicated which direction she thought the legal discourse should take when she described how the conviction opened up the possibility of

perpetrators being convicted even if the victim is passive. It is incumbent upon the man to realise the woman's situation, even if she does not express her fear or try to get away. If a woman is intoxicated the man must realise that she is perhaps not able to make adequate assessments.

(Göteborgs-Posten, GP, 9/9 1997)

This articulation opened up the possibility of placing the responsibility for the situation on the person who performed the sexual act; that which in the sexual offences legislation of 2018 would come to be laid down in a negligence requirement.

The term consent was also mentioned in relation to the conviction in the Supreme Court. Expressen predicted that

the judgment would have several positive effects. It will become easier for prosecutors to bring prosecutions in similar cases. The responsibility is transferred back from women to men, who must ensure that both or all parties have given their consent prior to having sex. [...] It is a partially new but entirely reasonable interpretation of the term 'helpless state'.

(Expressen, 11/9 1997)

The conviction thus opened for a discursive potential to connect consent and negligence to rape and sexual exploitation. This set out two alternative nodal points to force and helpless state.

Following the judgement, Freivalds said that it was a step in the right direction but that uncertainties remained 'within the area of sexual offences'. She announced that a government committee of inquiry would be appointed to 'clarify the terms' (TT, 10/9 1997). The terms of reference for the committee, called 1998 års Sexualbrottskommitté [the Sexual Offences Committee of 1998], stated that the alternative nodal point consent was to be investigated. The committee was to explicitly examine whether the requirements for violence, threat or a state of incapacitation could be replaced by a 'consent construction' (Leijonhufvud, 2015:44).

\section{The Tumba case, 2003}

A few years later, in 2001, the Sexual Offences Committee presented its report in which the matter of consent had been investigated. This report pointed out that the requirement for force could undeniably be seen as an obstacle to taking legal action against what 'rightfully should be punishable acts' (SOU, 2001:14, pp. 89f.). However, the committee did not go all the way and propose consent-based legislation, choosing instead to retain violence, threat or a state of incapacitation as prerequisites for the offence of rape. 
One of the arguments was that a prerequisite of consent risked leading to a 'reversed burden of proof', meaning that it was up to the man to prove that the woman had consented and not the other way around. A consent regulation was thus deemed to challenge another of the legal discourse's central nodal points - the principle of on whom the burden of proof lay (SOU, 2001:14, p. 128). This left the terms consent and negligence hanging in the air, while the terms violence, force and incapacitation were once again fixated as nodal points in the legal discourse through having been given new political legitimacy.

Nonetheless, other legislative changes were proposed, for example that the prerequisite for sexual exploitation, exploiting someone who is already 'helpless or in some other state of incapacitation', should be moved to the section on rape. I will return to this, but because the amendment did not happen until 2005 , the legal situation was unchanged at the time of the 'Tumba case'. 3

In February 2003, a 32-year-old mother of two was at a bar in Tumba, a Suburb outside Stockholm, together with a female friend. She met three younger men that she knew superficially. The party left the bar together and the men gave the woman a ride home. After that point, the woman has no memory and she suspected that she had been drugged, however this could not be proven. Once in the woman's apartment, the men carried out repeated oral and vaginal intercourse with the woman, sometimes several men at the same time. Further men came to the apartment, and a total of seven different men were suspected of having had intercourse with the woman over several hours. Between the instances of intercourse, the woman walked around the apartment, intoxicated and naked, smeared in semen.

Four men were prosecuted in Huddinge District Court for sexual exploitation. The media appeared to have learned the legal terminology after the Södertälje case and explained: 'The fact that the offence is classified as sexual exploitation is because the woman, by drinking alcohol, has contributed to being in what is called a "helpless state" (TT, 9/4 2003). The choice to legitimise in this instructive manner the court's classification of the offence suggests the hegemony of the legal discourse. However, the fact that there is any need to explain the court's definition reveals that this is obviously defined as rape outside of the legal discourse. In other words, the wording makes it clear that there was a discrepancy between the general conception of justice and the law.

As if to anticipate the criticism of the charges brought that was directed at the prosecutor in the Södertälje case, the public prosecutor admitted in Aftonbladet that 'because rape in colloquial terms is to have sex with someone who doesn't want to, I can see how it seems a bit odd that we lawyers classify it differently' (17/4 2003). The prosecutor here presumed that the general public, as opposed to the lawyers, had a perspective on rape that did not assume force, meaning instead a lack of consent.

Both Huddinge District Court and the Svea Court of Appeal acquitted the four men with the argument that the woman had not been in a helpless state. The judgements sparked strong reactions in the newspapers' editorial and 
opinion pages. 'A lone woman against four men, how is she supposed to defend herself regardless of whether she is sober or not? Can you be any more helpless than that?' (GP 29/4 2003). 'Blind drunk women are every man's property in Sweden. The court of appeal judgment in the Tumba group rape trial cannot be interpreted in any other way' (GP 5/11 2003). The criminal law professor Madeleine Leijonhufvud, who would become a leader in the political struggle for consent-based legislation, warned in Aftonbladet of what could happen unless there was change in how the law is applied: 'I see great, great anger emerging, not least among young women. [...] They are becoming a strong political force that are forcing a change to the law so that it actually protects them' (7/11 2003).

In addition to the term helpless state, the news reporting pinpointed another nodal point in the legal discourse that had not been discussed in the Södertälje case, that rape is a crime committed with intent. For a sexual act to be an offence, the perpetrator must be aware that the act is committed using force but chooses to carry on regardless. The district court's justification for the acquittal, as it was reported in the media, questioned whether there was intent:

The woman [had] voluntarily gone with the men in the car to the apartment. One of them had previously danced with her at a restaurant. She had reportedly behaved in a sexy manner. According to herself, she can be perceived as flirty. She was happy and giggly when she left the restaurant. 'Even though it may be difficult to understand how anyone voluntarily wants to be part of such activities as occurred in the apartment, this behaviour - from the men's point of view - cannot be considered so unnatural that it is proven that they had exploited the state she was in', the court writes.

$D N$ 's response to the acquittal in the court of appeal suggested that this hypothesis was perceived as ridiculous:

The woman was helpless when she was sexually exploited by several men. But they didn't understand that she was helpless because she was active. That was the court of appeal's reasoning when it acquitted four men in the much-discussed Tumba case.

The leader writer Maria Carlshamre described how the requirement for intent, combined with the lack of both a consent and a negligence prerequisite, deprived women of their rights:

Swedish legislation has an implied prerequisite: women are basically available for sexual intercourse - unless otherwise specified. On the other hand, men are not being held responsible for finding out whether women consent to 
intercourse. And if a woman finds herself in a helpless state, it is sufficient for the men to be too dumb to realise that for them to walk completely free.

(DN 4/11 2003)

This summed up what was perceived to be the problem with the nodal points that constituted the legal discourse on rape at that time - that in the legislation and in practice women were, as a rule, available and men were relieved of responsibility (cf. Andersson, 2004). At the same time, the possibility of an alternative legal discourse was articulated, one that was based not on force and intent but on consent and responsibility in a way that is similar to the sexual offences legislation of 2018.

The debate came to encompass the change to the legislation that had been announced in the debate concerning the Södertälje rape. As mentioned above, the Sexual Offences Committee of 1998 had presented its report in 2001 (SOU, 2001:14), but by 2003, no legislative change had been proposed. In the debate about the Tumba case, the social democrat government, represented by the new Minister of Justice Tomas Bodström, took the opportunity to launch the forthcoming proposal.

The question of whether it shall be possible to classify an assault as rape when a severely intoxicated woman is sexually exploited is one of the questions the Ministry of Justice is currently wrestling with. A new proposal will be presented before the end of the year [...]. Under this proposal, sexual assaults against severely intoxicated, sleeping or disabled people will in future be classified as rape.

$(\mathrm{SvD}, 14 / 10$ 2003)

It was evident here that the government had seized on the problem that in neither the Södertälje case nor the Tumba case had the prosecutor considered themselves able to prosecute for rape, choosing instead to classify the offences as sexual exploitation. Under this proposal, the solution was to allow more experiences of assault to be classified as rape. Some described the forthcoming legislative amendment as a solution to the legal dilemma. 'If this proposed new law had applied, the men would have been prosecuted for rape, not sexual exploitation' (Sydsvenskan, 5/11 2003).

However, many debaters were not satisfied. Instead, the demand for a consent prerequisite was again brought to the fore. "Amend the law so that the woman's consent it required!" is the new battle cry from all of those who have already tired of Bodström's legislative amendment before it has even come into force' reported Anna Dahlberg, leader writer at Expressen (20/11 2003).

In modern sexual offences legislation, the starting point must be that the person who wants to have sex is responsible for establishing whether this desire is reciprocated. The woman's duty to resist should be replaced by 
the man's duty to ensure there is consent wrote $D N$ 's leader writer Maria Carlshamre (4/11 2003).

However, in his response to the newspapers' critique, Bodström made it clear that the new law would not contain a consent prerequisite: 'Minister of Justice Bodström has finished considering this point: he says that if we reverse the burden of proof, Sweden risks ending up in the European Court of Justice' (GP, 6/11 2003). It became clear at this point that the legislature not only had the political duty to listen to the general public but was also forced to align with the legal discourse. Arguing that Sweden risked ending up in the European Court of Justice if the legislation was brought closer in line with the general conception of justice, Bodström clearly marked the boundaries of what changes to the legal discourse were possible. Rhetorically choosing to describe consentbased legislation - a format for the legislation that had already been applied in several countries - as a violation of one of the most important principles of the legal discourse - to 'reverse the burden of proof' - further legitimised the legislature's decision on this issue. Stating that he had 'finished considering this point' created a fixation of the legal discourse.

Despite the announcement that new legislation, which, if it had been in force when the Tumba case happened, could have resulted in a rape conviction, was on the way, the case was brought before the Supreme Court. This was interpreted by some to mean that the articulations of the discursive field had literally infiltrated the legal discourse. Expressen wrote that 'the lawyers for the accused claim that the Prosecutor-General had given in to popular opinion and that is why the case had been brought before the Supreme Court' (30/3 2004).

However, the actual reason why the case was brought was to examine the issue of intent. The Prosecutor-General said that:

It involves, among other things, making it clear what responsibility can be demanded of the suspects, of the three men in this case. If it is as the men say, that she was the instigator, it is still not OK to just go ahead. You may not take advantage of someone who is in no fit state to realise what she is offering.

(SvD, 31/3 2004)

In the Tumba case, just like in the Södertälje case, the Prosecutor-General opened up the possibility of a more empathetic approach to the victim's situation to be included in the legal discourse; in the quote, it is worded in a way that is reminiscent of the reasoning concerning negligence in the legislation of 2018.

Nevertheless, this approach was absent when the Supreme Court also chose to acquit the men. According to the media reporting, the argument was instead based once more on the fact that the women had not been in a helpless state:

There is no doubt that she was drunk and had lost her sense of judgement. However, this doesn't mean that she was in a helpless state of the 


\section{Gabriella Nilsson}

kind the law defines as grounds for it being an offence to have sexual relations with her.

(Aftonbladet, 5/5 2004a)

The legal vacuum between rape and sexual exploitation was again highlighted in the editorial pages of both Aftonbladet and Expressen: 'Either you have been forced to have sex or you have been so passed out that you have not been able to notice any sexual advances whatsoever. In between those situations, nothing criminal has occurred' (Expressen, 5/5 2004). 'In a legal sense, it is not possible to convict the men. In principle, this proves that the law, as it is currently worded, is based on a degrading view of mankind' (Aftonbladet, 5/5 2004b). It is 'a hard day for Swedish gender equality' is how Expressens leader writer Anna Dahlberg summed up the situation (5/5 2004).

\section{The Husby rape, 2006}

The new sexual offences legislation came into force on 1 April 2005 (Govt. Bill, 2004/05:45). The change that had the greatest relevance for the cases analysed here was the second paragraph of the section on rape where it was stipulated that someone could be convicted of rape who, in addition to violence and threat, performs sexual intercourse or a sexual act with a person:

[...] by unlawfully exploiting the fact that this person, due to being unconscious, asleep, intoxicated or under the influence of drugs in some other way, ill, injured or having some form of mental disorder, or, taking into account the circumstances, is otherwise in a helpless state.

(SFS, 2005:90, PC, Chapter 6, Section 1)

Here, the prerequisite for sexual exploitation - exploiting someone who already was in a helpless state - had been included in the prerequisite for the offence of rape and had also been specified through a list of possible situations in which a helpless state could exist. This change would make it possible to avoid the dilemma the prosecutors faced in both the Södertälje case and the Tumba case - the difficulty of prosecuting for rape. It was in this legal context that the Husby case occurred.

The night of the 14 May 2006, a 25-year-old woman visited a disco in central Stockholm. She drank alcohol and felt nauseous, which is why she chose to leave the place. On her way home, she met three unknown men who took her with them in an unlicensed taxi. The woman was taken to an apartment in Husby, a Suburb to Stockholm. Once there she has vague memories of two men having intercourse with her. In the morning, the woman is thrown out of the apartment and is encouraged by a friend to report the incident to the police. 
The Husby case was the first group rape case with media attention that would be tried under the new legislation. The prosecutor argued that the men had exploited the woman's helpless state and chose to prosecute them for aggravated rape. $S v D$ reminded the readers of why it was now possible to charge the men with rape: 'Under the new sexual offences legislation from 2005, sexual assaults against victims who are severely intoxicated are to be classified as rape rather than sexual exploitation' (25/10 2006). However, despite the amended legislation, Stockholm District Court acquitted the men. 'Difficulty with proof despite the new law' was the headline in Aftonbladet following the judgement (23/11 2006).

Again, it was the definition of the term helpless state that was the problem: "According to the district court, it is not possible to conclude that the woman was in a helpless state and there are therefore no grounds on which to examine whether she was the victim of rape' (Expressen, 22/11 2006). The acquittal showed that, more than ten years after the Supreme Court set the precedent that a helpless state could mean 'being vulnerable to unknown men in unknown locations' in its judgement in the Södertälje case, the legal discourse could still use the level of intoxication as a measurement of helpless state.

The victim's lawyer expressed her surprise at the judgement, according to the newspaper Metro:

Even though there is new sexual offences legislation that is supposed to protect victims of crime who are under the influence of alcohol and drugs, we are stuck in a situation where assessments are being made under the old legislation. If we don't change our viewpoint, we'll never be able to take legal action against this type of men's violence against women.

With this statement, the lawyer gave legal legitimacy to the new law and instead directed her criticism inwards, towards the actors within the legal discourse and their inability to read the new law in the way the legislature intended.

It is conceivable that the district court judgement in the Husby case was perceived as problematic by the government that had pushed the legislation through and put their faith in it working. Thus, it might have been a relief when the Svea Court of Appeal sentenced the men to imprisonment for rape when the judgement in the Husby case was appealed against the following year. Aftonbladet wrote that

The court of appeal is of the opinion, in contrast to the district court, that it is beyond reasonable doubt that the men have raped the now 27-year-old woman. According to the court of appeal, the men have exploited the woman's helpless state and they were also well aware of this. 


\section{Gabriella Nilsson}

The judgement confirmed that the men had exploited the woman and that they did this with intent. In that respect, the judgement can be seen as a defence of the new legislation and as a reflection of the fact that the legal discourse and the general conception of justice were in accord.

\section{The Tensta rape, 2013}

After the Husby rape, the sexual offences legislation was however still debated. The government therefore decided to set up a special inquiry, the 2008 Sexual Offences Inquiry, tasked with evaluating the application of the 2005 sexual offences reform. This assignment included once more investigating and determining whether the current requirement for force as a basis for criminal liability for rape should be replaced with a requirement for a lack of consent.

In its report, the inquiry argued that even though the protection of personal and sexual integrity as well as sexual self-determination had been reinforced through the new legislation, the term helpless state was considered too limited to cover all acts where the perpetrator had exploited the situation the victim was in (SOU, 2010:71). Following this inquiry, the government however once again made the assessment that the disadvantages that a consent regulation would entail were not outweighed by the advantages (Leijonhufvud, 2015, p. 75). Instead, the result of the inquiry was that the government proposed a minor amendment to the second paragraph of the rape section, which meant that the term helpless state was replaced with the broader term 'particularly vulnerable situation' (Govt. Bill, 2012/13:111). The legislature argued that, by doing so, several of the acquittals covered heavily in the media could be avoided in future. However, before the change came into force on 1 July 2013, the Tensta case occurred.

On 2 March 2013, a 15-year-old girl went with two female friends to the Stockholm suburb of Tensta to attend a private party. In the apartment were eight similarly aged boys who the girl did not know. Later on, when one of the friends had gone home and the other was very intoxicated, the girl was in a bedroom where she had intercourse with one of the boys. Subsequently a situation occurred where five other boys lined up to have intercourse with the girl. The girl said that she did not want to, but the boys repeatedly had intercourse with her. They had taken her jacket and phone and at times the room was locked. When the boys were finished, the girl left the apartment and reported the incident to the police.

In June 2013, Solna District Court found five boys guilty of aggravated rape. 'In legal terms, the girl was in a helpless state. She was outnumbered, she did not know the boys, they were obtrusive, and she was afraid of them beating her up if she did not do as they said' (TT 14/6, 2013). TT's reporting of the judgement indicates that the district court appears to have used the broader definition of helpless state that had been applied by the Supreme Court in its assessment 
of the Södertälje case. Helpless state was described as being possible to define as a subjective experience of fear, and not directly related to the level of intoxication not just in the general conception of justice but also in legal terms.

However, the judgement was appealed and the Svea Court of Appeal acquitted the boys in September 2013. The judge explained to Aftonbladet that 'the intercourse that took place could very likely have occurred against her expressed will, but if it is not exploitation of a helpless state, it is not rape' (28/9 2013). The court of appeal judge here defended the acquittal by reminding us that the new legislation was not based on a consent prerequisite intercourse that took place against someone's will was not by definition illegal. However, critics argued that the judgement did not pertain to deficiencies in the legislation, rather to lawyers' 'male perspective' (Kvällsposten, 5/10 2013).

The fact that the court considers it possible that the boys would not be aware of the imbalance of power in that room and would not be able to understand that the girl was afraid shows a shockingly low faith in boys' ability to be sympathetic and to assess reciprocity.

(Expressen, 27/9 2013a)

This problematises, once again, the term intent and what responsibility should be demanded of the person who actively carried out the sexual act.

Between the conviction in the district court and the acquittal in the court of appeal, the amendment from helpless state to particularly vulnerable situation had entered into force, which is why the reporting of the Tensta case came, to some extent, to be characterised by a sense of hope for the future. 'You can read between the lines of the court of appeal's grounds for the judgement that if it had been possible to apply the new law, they would have been convicted' (Expressen, 27/9 2013b). However, the acquittal was not just debated in terms of hope, the debate was also suffused with a resignation to the fact that the legislation always seemed to be one step behind reality; that the legislature acted reactively rather than proactively. Expressen's Maria Rydhagen wrote that 'when it comes to rape, the law is like a tone-deaf drunk [...]. I think few Swedes support or even understand the Svea Court of Appeal judgement that was announced yesterday' (28/9 2013). Instead, the judgement gave rise to new demands for consent-based regulation:

One proposal that has been brought up again is a requirement for consent for sex. [...] After this judgment in the Svea Court of Appeal, this proposal should be properly examined. In a democracy, courts cannot in the long run go against people's sense of justice.

(Aftonbladet, 1/10 2013)

Evidently, as the legal discourse had failed time and again to achieve convictions in cases that seemed clear-cut in the general conception of justice, its hegemony was weakened and alternative nodal points such as consent appeared 
increasingly attractive, even among members of parliament. There was now a political 'breeding ground' for a change towards consent-based legislation (Expressen, 6/10 2013).

On 28 August 2014, the government decided to set up a special inquiry with the task of once again reviewing the offence of rape, an inquiry that was later reorganised into the 2014 Sexual Offences Committee. Two years later, on October 2016, the Committee recommended a consent-based legislation (SOU, 2016:16). After a long period of referral for consideration and comment, the government bill was presented in parliament, which was adopted on 23 May 2018. Consent-based legislation entered into force in Sweden on 1 July 2018.

\section{Conclusion}

I have shown how the amendment to the sexual offences legislation in 2018 is the result of a discursive process in which the terms 'consent' and 'negligence' have been gradually introduced, heavily debated and slowly implemented in the legal discourse over a period of more than twenty years. Theoretically, I have shown how the legal shift from a force-based legislation to a consent-based construction is the result of an ongoing interplay between challenging articulations on the discursive field and attempts to fixate the meaning of terms on the legal discourse. By definition, continuous attempts to fixate nodal points is what constitutes a discourse (Laclau \& Mouffe, 1985).

Although a consent-based legislation has come into force in other countries far earlier than in Sweden, this has not been utilised in the Swedish debate, neither as an argument for nor against such a legal construction. Instead, the aim of this chapter has been to show that the discursive field where this legal process took shape has been the news reports and debate about a number of hyper-medialised Swedish group rape cases. News reports and debate about these cases have formed the arena where the voices of the law have been both defending the legal discourse and highlighting its dilemmas, such as the various potential meanings of 'helpless state' and the crack between the offences rape and sexual exploitation. The cases have also formed the arena where representatives of the legislator have attempted to meet the demands for a change expressed in the public opinion and bridge the discrepancy between the general conception of justice and the law.

It is clear that in Sweden, the appointment of government committees of inquiry plays a crucial part in the development and implementation of political reform. In fact, Swedish historian Sara Edenheim has shown that appointing a committee might be of greater political value than to actually implementing its recommended change (2005). However, news media is central in this political process, and specifically the news reports about group rape cases have offered a sufficiently turbulent situation for the challenging articulations on the discursive field to have an impact (cf. Nilsson, 2018). The news reports of the legal discourse failing time and again to achieve convictions in cases that seemed clear-cut in the general conception of justice weakened its hegemony and gradually made the alternative nodal point consent appear increasingly 
attractive, even among members of parliament. With the new legislation that entered in force in July 2018 (SFS 2018:618), it remains to be seen how the various potential meanings of consent, or voluntariness, and liability for negligence will be interpreted.

\section{Notes}

1 All quotes from newspaper articles have been translated from Swedish by the author.

2 All summaries are made by the author and are based on the information given about the cases in the news.

3 The law was unchanged apart from a minor amendment that was adopted as part of the Kvinnofridspropositionen [the Women's Peace Bill] (Govt. Bill, 1997/98:55).

\section{References}

Aftonbladet 24/4 1997. Rätten friade gruppvåldtäkt. News article, unsigned.

Aftonbladet 17/4 2003. Åtalade för grovt sexbrott. Släpps i väntan på dom. News article, Cecilia Gustavsson.

Aftonbladet 23/11 2006. Tre går fria från gruppvåldtäkt. Bevissvårigheter trots nya lagen. News article, unsigned.

Aftonbladet 7/11 2003. Dags att förbjuda alla sexuella övergrep. Debate article, Madeleine Leijonhufvud.

Andersson, Ulrika, 2004. Hans (ord) eller hennes? En könsteoretisk analys av straffrättsligt skydd mot sexuella övergrepp. Lund: Bokbox Förlag.

Aftonbladet 5/5 2004a. 'Jag ångrar inte anmälan'. News article, Cecilia Gustavsson.

Aftonbladet 5/5 2004b. Ändra lagen om sexbrott. Unsigned editorial.

Aftonbladet 5/10 2007. Friade för våldtäkt fällda i hovrätten. News article, unsigned.

Aftonbladet 1/10 2013. Våldtäkt borde inte vara lagligt. Editorial, Anders Lindberg.

Aftonbladet 28/9 2013. Domaren: Hon kan mycket väl ha sagt nej. News article, Anders Clark.

Aftonbladet 17/12 2017. Regeringen inför samtyckeslag - sex ska vara frivilligt. News article.

Andersson, Ulrika, Edgren, Monika, Karlsson, Lenaoch \& Nilsson, Gabriella, 2016. Våldtäkt i Sverige 1990-2013: ett historiskt och intersektionellt perspektiv på berättelser om våldtäkt i olika genrer. Gränsløs. Tidskrift för studier av Öresundsregionens historia, kultur och samhällsliv, 6: 82-92.

Bumiller, Kristin, 2008. In an abusive state. How neoliberalism appropriated the feminist movement against sexual violence. Durrham: Duke University Press.

Dagens Nyheter 25/8 1997. Hjälplös nog att bli utnyttjad? Södertäljemålet i HD. News article, Ulrika By.

Dagens Nyheter 6/5 1997. Den friande domens försvar. Unsigned editorial.

Dagens Nyheter 30/4 1997a. Södertäljemålet: Sexdom kan bli fall för HD. News article, Ulrika By.

Dagens Nyheter 30/4 1997b. Driv Södertäljemålet till HD. Nu måste det klargöras vad en våldtäkt egentligen är. Debate article, Billy Butt och Annika Hjelmqvist.

Dagens Nyheter 2/12 2003. Tumbadomen prövas av HD. News article, Peter Letmark.

Dagens Nyheter 4/11 2003. Dags att förändra våldtäktslagen. Editorial, Maria Carlshamre. 


\section{Gabriella Nilsson}

Edenheim, Sara, 2005. Begärets lagar. Moderna statliga utredningar och heteronormativitetens genealogi. Stockholm/Stehag: Brutus Östlings Bokförlag Symposion.

Expressen 11/9 1997. Hjältinnan. Unsigned editorial.

Expressen 24/4 1997. De måste straffas. News article, Challe Lundholm.

Expressen 20/11 2003. Var är juristerna? Editorial, Anna Dahlberg.

Expressen 30/3 2004. Sexoffrets sista chans. News article, unsigned.

Expressen 5/5 2004. De tror inte på kvinnan. HD friar männen från övergrepp vid gruppsex. Editorial, Anna Dahlberg.

Expressen 22/11 2006. Frias från gruppvåldtäkt i Husby. News article, unsigned.

Expressen 6/10 2013. Nät-ilska kan hjälpa. Experten: 'På lång sikt påverkas politikerna och lagstiftningen'. News article, Karl-Johan Karlsson.

Expressen 28/9 2013. Juridik och moral är olika saker när de gäller våldtäkt. Editorial, Maria Rydhagen.

Expressen 27/9 2013a. Alhem: Med den nya lagen hade de fällts. News article, Stina Loman.

Expressen 27/9 2013b. Frias för gruppvåldtäkt - rummet var för mörkt, News article. Rebecka Martikainen

Göteborgs-Posten 9/9 1997. Vilken väg väljer rätten? Imorgon avgör Högsta domstolen Södertäljefallet. News article, Eva Parkrud.

Göteborgs-Posten 29/4 2003. En kvinna är hjälplös mot fyra män! Editorial, Carina Andersson.

Göteborgs-Posten 5/11 2003. Kvinnan rättslös snarare än fredad. Unsigned editorial.

Göteborgs-Posten 6/11 2003. Skärpta sexlagar nästa år. News article, Björn Svensson.

Govt. Bill 1997/98:55. Kvinnofrid. Regeringens proposition.

Govt. Bill 2004/05:45. En ny sexualbrottslagstiftning. Regeringens proposition.

Govt. Bill 2012/13:111. En skärpt sexualbrottslagstiftning. Regeringens proposition.

Govt. Bill 2017/18:177. En ny sexualbrottslagstiftning byggd på frivillighet. Regeringens proposition.

Kvällsposten 5/10 2013. 'Domen är felaktig' - Sven-Erik Alhem sågar hovrätten i våldtäktsmålet? News article, Eva Rogsten.

Laclau, Ernesto \& Mouffe, Chantalle, 1985. Hegemony and socialist strategy. Towards a radical democratic politics. London and New York: Verso.

Leijonhufvud, Madeleine, 2015. Svensk sexualbrottslag. En framåtsyftande tillbakablick. Stockholm: Norstedts juridik.

McGlynn, Clare \& Munroe, Vanessa E. (eds), 2010. Rethinking rape law: International and comparative perspectives. Oxford and New York: Routledge.

Metro 24/11 2006. Nu förstår jag varför flickor inte anmäler. News article, Anna Hagman.

Nilsson, Gabriella., 2018. Rape in the news: On rape genres in Swedish news coverage. Feminist Media Studies. Published online. https://doi.org/10.1080/14680777.2018.1513412

SFS 1984:399, BrB kap. $61 \S, 3 \S$.

SFS 2005:90, BrB kap. $61 \S$.

SFS 2018:618, BrB kap. $61 \S$.

SOU 2001:14. Sexualbrotten - Ett ökat skydd för den sexuella integriteten och angränsande frågor. Betänkande av 1998 års Sexualbrottskommitté.

SOU 2010:71. Sexualbrottslagstiftningen - utvärderingen och reformförslag. Betänkande av 2008 års sexualbrottsutredning.

SOU 2016:60. Ett starkare skydd för den sexuella integriteten. Betänkande av 2014 års sexualbrottskommitté. 
Spohn, Cassia \& Horney, Julie, 2013. Rape law reform: A grassroots revolution and its impact. New York: Plenum Press.

Svenska Dagbladet 3/5 1997. Svea hovrätt hade inga andra möjligheter än att fria. Debate article, Peter Löfmarck.

Svenska Dagbladet 30/5 1997. Våldtäktsmål kan leda till skärpt lag. News article, Bosse Brink.

Svenska Dagbladet 4/5 1997. Juridiska missar om våldtäkt. Unsigned editorial.

Sydsvenskan 5/11 2003. Prövning i HD inte trolig. News article, Bibi Häggström.

Svenska Dagbladet 14/10 2003. Kritiserat domslut i sexmål prövas igen. News article, Daniel Kjellberg.

Svenska Dagbladet 31/3 2004. Uppsåt avgör dom i Tumbamålet. News article, unsigned.

Svenska Dagbladet 25/10 2006. Tre åtalas för våldtäkt av berusad ung kvinna. News article, Christina Wahldén

TT 10/9 1997. HD dömer tre män för våldtäkt och sexövergrepp på 18-årig. News telegram.

TT 25/4 2003. Fyra frikända i gruppsexmål. News telegram.

TT 9/4 2003. Fyra män åtalade för sexövergrepp på kvinna. News telegram.

TT 14/6 2013. Tveklös dom om gruppvåldtäkt. News telegram.

Wennstam, Katarina, 2002. Flickan och skulden: en bok om samhällets syn på våldtäkt. Stockholm: Bonnier. 